\title{
Soil chemical properties and nutrients in maize fertilized with urban waste compost ${ }^{1}$
}

\author{
José Ricardo Mantovani², Fernando Spadon ${ }^{3}$
}

\section{ABSTRACT}

Urban waste compost has a potential to be used as an organic fertilizer in agriculture, but field studies are required to define the recommendable rates for crops. This study aimed at evaluating the effect of fertilization with urban waste compost on the soil chemical properties, yield, nutrient and heavy metal contents, in maize leaves and grains. The field experiment was carried out in a randomized complete block design, with seven treatments and four replications. The treatments consisted of six urban waste compost doses (0 $\mathrm{Mg} \mathrm{ha}^{-1}, 5 \mathrm{Mg} \mathrm{ha}^{-1}, 10 \mathrm{Mg} \mathrm{ha}^{-1}, 20 \mathrm{Mg} \mathrm{ha}^{-1}, 30 \mathrm{Mg} \mathrm{ha}^{-1}$ and $40 \mathrm{Mg} \mathrm{ha}^{-1}$ ), applied in the planting furrow, plus an additional control treatment, with NPK mineral fertilization and no waste compost application. Fertilization with up to $40 \mathrm{Mg} \mathrm{ha}^{-1}$ of urban waste compost improves soil fertility. Fertilization with urban waste compost increases grain yield and the $\mathrm{N}, \mathrm{P}$ and $\mathrm{K}$ contents in leaf tissue and maize grains, without inducing plant contamination with heavy metals. The application of $30 \mathrm{Mg} \mathrm{ha}^{-1}$ of urban waste compost can replace mineral fertilization in maize cultivation.

KEYWORDS: Organic fertilization; soil fertility; heavy metals.

\section{INTRODUCTION}

The availability of organic, agroindustrial and urban waste in Brazil is high, and the exploitation of these residues in agriculture as a source of nutrients and organic matter is a beneficial alternative for the environment and may reduce the amount of mineral fertilizers applied in some areas (Carneiro et al. 2013, Paula et al. 2013, Somavilla et al. 2014).

Among the organic residues, urban waste is generated at staggering rates in Brazilian cities, where each inhabitant produces daily $1.07 \mathrm{~kg}$ of garbage, on average, which is mainly disposed in dumps and landfills (Abrelpe 2015). A significant

\section{RESUMO}

Atributos químicos do solo e nutrientes em milho adubado com composto de lixo urbano

O composto de lixo urbano tem potencial de uso na agricultura como fertilizante orgânico, mas estudos em condições de campo são necessários para a definição das doses recomendadas para as culturas. Objetivou-se avaliar o efeito da adubação com composto de lixo urbano nos atributos químicos do solo, produtividade, teores de nutrientes e de metais pesados, nas folhas e grãos de milho. O experimento foi realizado a campo, empregando-se delineamento experimental em blocos ao acaso, com sete tratamentos e quatro repetições. Os tratamentos foram constituídos por seis doses de composto de lixo urbano (0 Mg ha ${ }^{-1}, 5 \mathrm{Mg} \mathrm{ha}^{-1}, 10 \mathrm{Mg} \mathrm{ha}^{-1}, 20 \mathrm{Mg} \mathrm{ha}^{-1}, 30 \mathrm{Mg} \mathrm{ha}^{-1} \mathrm{e}$ $40 \mathrm{Mg} \mathrm{ha}^{-1}$ ), aplicadas no sulco de semeadura, além de um tratamento adicional, com adubação mineral NPK e sem adubação com composto de lixo. A aplicação de até $40 \mathrm{Mg} \mathrm{ha}^{-1}$ de composto de lixo urbano melhora as condições de fertilidade do solo. Aadubação com composto de lixo urbano aumenta a produtividade de grãos e os teores de N, Pe K no tecido foliar e nos grãos de milho, sem provocar contaminação da planta com metais pesados. A aplicação de $30 \mathrm{Mg} \mathrm{ha}^{-1}$ de composto de lixo urbano pode substituir a adubação mineral, em cultivo de milho.

PALAVRAS-CHAVE: Adubação orgânica; fertilidade do solo; metais pesados.

part of the garbage produced in Brazil has an organic composition (e.g. food leftovers and plant remains) and has a potential for composting (Silva 2008).

Urban waste compost improves the soil chemical and physical properties (Mantovani et al. 2005, Moraes et al. 2014). However, since the garbage usually also contains batteries, paint, insecticides, cleaning agents and light bulbs mixed with the organic fraction, the urban waste compost may contain significant amounts of toxic heavy metals such as $\mathrm{Cd}, \mathrm{Ni}, \mathrm{Pb}$ and $\mathrm{Cr}$, which can contaminate soil and plants (Sampaio et al. 2009).

Urban waste compost can be used in agriculture as a seedling substrate (Lima et al. 2011) and in the

1. Manuscript received in Feb./2017 and accepted for publication in Jun./2017 (http://dx.doi.org/10.1590/1983-40632016v4745475).

2. Universidade José do Rosário Vellano, Faculdade de Agronomia, Alfenas, MG, Brazil. E-mail: mantovanijr@yahoo.com.

3. Universidade do Estado de Minas Gerais, Laboratório de Solos, Passos, MG, Brazil. E-mail: spadonf@yahoo.com.br. 
cultivation of flowers (Farias et al. 2013), vegetables (Sampaio et al. 2009), sugarcane (Nobile et al. 2012) and grain crops (Strojaki et al. 2013). However, few field studies have addressed the fundamental issue of defining adequate and safe rates of this organic fertilizer for crops, in Brazil.

The purpose of this study was to evaluate the effect of fertilization with urban waste compost on soil chemical properties, maize yield, nutrient and heavy metal concentrations in maize leaves and grains, as well as in the soil.

\section{MATERIAL AND METHODS}

This field experiment was carried out in Passos, Minas Gerais state, Brazil, from November 2014 to May 2015. The soil of the experimental area was classified as a Dystrophic Red Latosol, medium texture (Embrapa 2013), where maize was grown as the main crop in the 2012/2013 and 2013/2014 growing seasons, in a conventional system followed by a fallow period.

During the experiment, the temperature varied from $16{ }^{\circ} \mathrm{C}$ to $28{ }^{\circ} \mathrm{C}$ and the cumulative rainfall in the period was $595 \mathrm{~mm}$ (Figure 1).

Prior to the experiment, soil samples were collected from the 0-0.2 cm layer for chemical (Raij et al. 2001) and particle-size analyses (Camargo et al. 2009) (Table 1).

The urban waste compost used in the experiment was obtained from the Solid Waste Sorting and
Composting Facility of the city of Jacuí, Minas Gerais state, where selective sorting is performed. In this plant, after the sorting and separation of inorganic components, the organic waste fraction, consisting basically of food leftovers, was heaped in rows in yards for natural composting, watered when necessary and periodically shifted to improve aeration, for 120 days. The resulting urban waste compost was analyzed on a dry basis, according to Tedesco et al. (1995), for estimates of moisture concentration, $\mathrm{pH}$ and chemical composition (Table 2). The heavy metal concentrations of this organic residue were below the maximum threshold determined for organic fertilizers and soil conditioners (Brasil 2006).

The soil was tilled with a disk harrow, followed by two diskings with a leveling harrow.

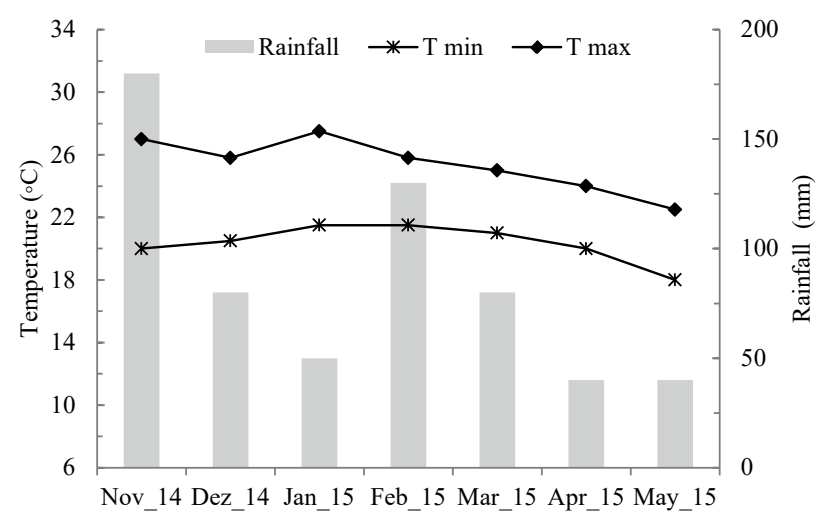

Figure 1. Air temperature and precipitation during the experiment.

Table 1. Soil chemical properties and particle-size characteristics of the experimental area.

\begin{tabular}{|c|c|c|c|c|c|c|c|c|c|c|c|}
\hline Layer & $\mathrm{OM}$ & $\mathrm{pH}$ & Resin P & $\mathrm{K}^{+}$ & $\mathrm{Ca}^{2+}$ & $\mathrm{Mg}^{2+}$ & $\mathrm{Al}^{3+}$ & $\mathrm{H}+\mathrm{Al}$ & SB & CEC & $\mathrm{V}$ \\
\hline $\mathrm{m}$ & $\mathrm{g} \mathrm{dm}^{-3}$ & $\mathrm{CaCl}_{2}$ & $\mathrm{mg} \mathrm{dm}^{-3}$ & & & 2 & $\mathrm{nmol}_{\mathrm{c}}$ & & & & $\%$ \\
\hline $0.0-0.2$ & 18 & 5.5 & 16 & 4.6 & 36 & 10 & 1 & 28 & 50.6 & 78.6 & 64 \\
\hline $0.2-0.4$ & 15 & 5.2 & 7 & 3.4 & 22 & 6 & 1 & 29 & 31.4 & 60.4 & 52 \\
\hline Layer & \multicolumn{2}{|c|}{$\mathrm{SO}_{4}{ }^{2-} \mathrm{S}$} & $\mathrm{B}$ & $\mathrm{Cu}$ & $\mathrm{Fe}$ & $\mathrm{Mn}$ & $\mathrm{Zn}$ & Clay & Silt & & \\
\hline $\mathrm{m}$ & \multicolumn{7}{|c|}{$\mathrm{mg} \mathrm{dm}^{-3}$} & \multicolumn{4}{|c|}{$\mathrm{g} \mathrm{kg}^{-1}$} \\
\hline $0.0-0.2$ & \multirow{2}{*}{\multicolumn{2}{|c|}{$\begin{array}{l}3 \\
3\end{array}$}} & 0.31 & 1.2 & 30 & 9.8 & 2.8 & 266 & 256 & \multicolumn{2}{|c|}{478} \\
\hline $0.2-0.4$ & & & 0.18 & 1.2 & 21 & 5.9 & 1.5 & 279 & 267 & & \\
\hline
\end{tabular}

OM: organic matter; $\mathrm{H}+\mathrm{Al}$ : potential acidity; SB: sum of bases; CEC: potential cation exchange capacity; V: base saturation.

Table 2. Water concentration, $\mathrm{pH}$ and chemical composition (dry basis) of the urban waste compost used in the experiment.

\begin{tabular}{|c|c|c|c|c|c|c|c|c|}
\hline Moisture & \multirow{2}{*}{$\mathrm{pH}$} & \multirow{2}{*}{$\mathrm{C} / \mathrm{N}$} & Organic C & $\mathrm{N}$ & $\mathrm{P}$ & $\mathrm{K}$ & $\mathrm{Ca}$ & $\mathrm{Mg}$ \\
\hline$\%$ & & & \multicolumn{6}{|c|}{$-\mathrm{g} \mathrm{kg}^{-1}$} \\
\hline 28 & 7.4 & $13 / 1$ & 282 & 22 & 11 & 7 & 42 & 3 \\
\hline $\mathrm{Cu}$ & $\mathrm{Fe}$ & $\mathrm{Mn}$ & $\mathrm{Zn}$ & $\mathrm{Cd}$ & $\mathrm{Cr}$ & $\mathrm{Ni}$ & $\mathrm{Pb}$ & \\
\hline & & & - $\mathrm{ng} \mathrm{kg}^{-}$ & & & & & \\
\hline 175 & 3,273 & 265 & 312 & 3 & 175 & 50 & 103 & \\
\hline
\end{tabular}


The experimental area was not limed, since the base saturation $(\mathrm{V} \%)$ in the soil surface layer $(0-0.2 \mathrm{~m})$ was close to that considered adequate for the crop (Raij et al. 1997).

Each plot was $5 \mathrm{~m}$ long and consisted of five plant rows spaced $0.5 \mathrm{~m}$ apart, resulting in a total area of $12.5 \mathrm{~m}^{2}$. The evaluated area was the three central rows, disregarding $1.0 \mathrm{~m}$ at either end, resulting in a useful area of $6 \mathrm{~m}^{2}$.

A randomized complete block design was used, with seven treatments and four replications, resulting in a total of 28 plots. The treatments consisted of six urban waste compost rates $\left(0 \mathrm{Mg} \mathrm{ha}^{-1}, 5 \mathrm{Mg} \mathrm{ha}^{-1}\right.$, $10 \mathrm{Mg} \mathrm{ha}^{-1}, 20 \mathrm{Mg} \mathrm{ha}^{-1}, 30 \mathrm{Mg} \mathrm{ha}^{-1}$ and $40 \mathrm{Mg} \mathrm{ha}^{-1}$ ), defined as a function of the $\mathrm{N}$ concentration of the organic residue, with an additional treatment in which N-P-K mineral fertilizer was applied and no organic fertilization with urban waste compost was carried out.

The urban waste compost rates were regularly distributed by hand in the sowing furrow, at 10 days before the maize sowing. Fertilization at sowing in the additional treatment was applied as proposed by Raij et al. (1997), for an expected yield above $10 \mathrm{Mg} \mathrm{ha}^{-1}$. For that, $30 \mathrm{~kg} \mathrm{ha}^{-1}$ of $\mathrm{N}, 70 \mathrm{~kg} \mathrm{ha}^{-1}$ of $\mathrm{P}_{2} \mathrm{O}_{5}$ and $50 \mathrm{~kg} \mathrm{ha}^{-1}$ of $\mathrm{K}_{2} \mathrm{O}$ were applied by hand in the sowing furrow, using urea, monoammonium phosphate and potassium chloride.

The total amounts of nutrients applied in the treatments fertilized with urban waste compost are shown in Table 3.

Maize was sown by hand on November 17, 2014, planting 6 seeds $\mathrm{m}^{-1}$. The 2B610 PW hybrid was used, with application of Bt-insecticide (Bacillus thuringiensis). After seedling emergence, thinning was carried out in the phenological stage V2, leaving 4 plants per meter in the rows, i.e., a population of 66,667 plants per hectare and 100 plants per plot.

Sidedressing was only applied in the additional treatment at the stage V4, as recommended by Raij et al. (1997), with application of $90 \mathrm{~kg} \mathrm{ha}^{-1}$ of $\mathrm{N}$ in form of urea in the row, next to the plants, and incorporation with a hoe, to avoid $\mathrm{N}$ volatilization losses. Weeds were controlled by hand and no insecticide application for pest control was required.

When about $50 \%$ of the maize plants had tasseled, leaves from the ear base were collected from 15 plants of the useful area of each plot (Raij et al. 1997) to determine the concentrations of $\mathrm{N}, \mathrm{P}$, $\mathrm{K}, \mathrm{Ca}, \mathrm{Mg}, \mathrm{S}, \mathrm{B}, \mathrm{Cu}, \mathrm{Fe}, \mathrm{Mn}, \mathrm{Zn}, \mathrm{Cd}, \mathrm{Cr}, \mathrm{Ni}$ and $\mathrm{Pb}$, according to the procedures described by Tedesco et al. (1995).

At 134 days after sowing, all ears were harvested from the plot area to determine yield, at a moisture concentration corrected to $13 \%$. In 15 randomly sampled ears of the evaluated area per plot, the following traits were also assessed: ear diameter and length, measured with a digital caliper and tape measure; number of grains per ear; and 1,000-grain weight.

From each plot, $0.2 \mathrm{~kg}$ of grains were collected, which were dried to constant weight and ground in a Willey mill to determine the concentrations of the same chemical elements evaluated in the leaf tissue (Tedesco et al. 1995).

After maize harvest, the soil in the evaluated area of each plot was sampled, from the application range of urban waste compost, in the layers of $0-0.2 \mathrm{~m}$ and 0.2-0.4 m, with a steel probe. A composite sample per layer was blended from 15 single samples. The following chemical properties were determined in the soil samples: $\mathrm{pH}$ in $\mathrm{CaCl}_{2}, \mathrm{H}+\mathrm{Al}$, organic matter, P-resin, $\mathrm{K}^{+}, \mathrm{Ca}^{2+}, \mathrm{Mg}^{2+}$, available $\mathrm{S}, \mathrm{B}, \mathrm{Cu}$, $\mathrm{Fe}, \mathrm{Mn}, \mathrm{Zn}, \mathrm{Cd}, \mathrm{Cr}$, $\mathrm{Ni}$ and $\mathrm{Pb}$, according to Raij et al. (2001). The $\mathrm{Cu}, \mathrm{Fe}, \mathrm{Mn}, \mathrm{Zn}, \mathrm{Zn}, \mathrm{Cd}, \mathrm{Cr}, \mathrm{Ni}$ and $\mathrm{Pb}$ concentrations in the soil, plant tissue and grain extracts were analyzed by optical emission spectrometry (ICP-OES).

The data of soil chemical properties of each layer, nutrient and heavy metal concentrations in the

Table 3. Nutrient supply by application of urban waste compost.

\begin{tabular}{cccccc}
\hline Urban waste compost rate & $\mathrm{N}$ & $\mathrm{P}$ & $\mathrm{K}$ & $\mathrm{Ca}$ & $\mathrm{Mg}$ \\
\hline Mg ha $^{-1}$ & & & - & - & - \\
$\mathrm{kg} \mathrm{ha}$ & & \\
\hline 0 & 79.2 & 39.6 & 25.2 & 151.2 & 10.8 \\
10 & 158.4 & 79.2 & 50.4 & 302.4 & 21.6 \\
20 & 316.8 & 158.4 & 100.8 & 604.8 & 43.2 \\
30 & 475.2 & 237.6 & 151.2 & 907.2 & 64.8 \\
40 & 633.6 & 316.8 & 201.6 & $1,209.6$ & 86.4 \\
\hline
\end{tabular}


leaf tissue and maize grains, maize yield and yield components were subjected to analysis of variance by means of the F test. When the treatment effect was significant, a polynomial regression analysis was performed. The comparison between the treatments fertilized with urban waste compost rates and the additional treatment with N-P-K mineral fertilization was carried out by partitioning the degrees of freedom of the treatments by the method of contrasts.

\section{RESULTS AND DISCUSSION}

Fertilization with urban waste compost in the maize planting furrow promoted a decrease in soil acidity in the 0-0.2 $\mathrm{m}$ layer, as the $\mathrm{pH}$ increased linearly and potential acidity $(\mathrm{H}+\mathrm{Al})$ decreased linearly, in response to the urban waste compost rates (Figures $2 \mathrm{a}$ and $2 \mathrm{~b}$ ). The highest rate of urban waste compost $\left(40 \mathrm{Mg} \mathrm{ha}^{-1}\right)$ increased the $\mathrm{pH}$ in $\mathrm{CaCl}_{2}$ to 6.3 , corresponding to a unit increase of 0.8 , and $\mathrm{H}+\mathrm{Al}$ decreased by $27 \%$, in relation to the control. As a result, the acidity in this layer declined from medium to very low, based on the interpretation criteria of soil fertility proposed by Raij et al. (1997).

The decrease of soil acidity after the urban waste compost application, even in the deeper layer, can be attributed to the probable composition of this residue. According to Mantovani et al. (2005), it contains water-soluble organic anions (R-COO- and $\mathrm{R}-\mathrm{O}-$ ), which, when released, can adsorb $\mathrm{H}^{+}$from the soil solution by exchange reactions, involving mainly $\mathrm{Ca}^{2+}$ ions. Another explanation is the production of

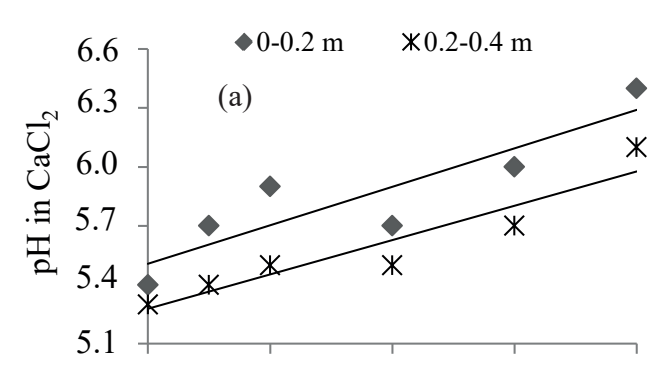

y $0-0.2=0.019 x+5.510 ; \mathrm{R}^{2}=0.765^{* *}$

y $0.2-0.4=0.018 x+5.254 ; \mathrm{R}^{2}=0.884 * *$

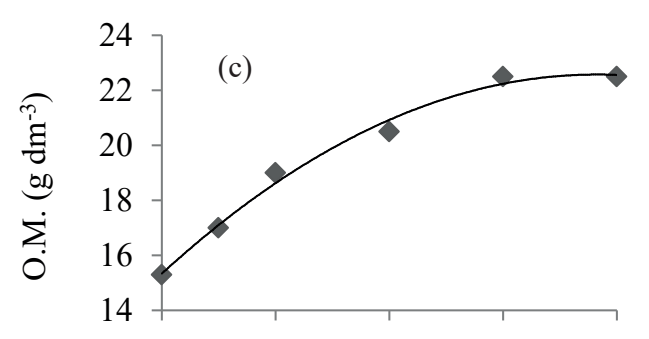

$y=-0.005 x^{2}+0.382 x+15.303 ; R^{2}=0.991^{* *}$

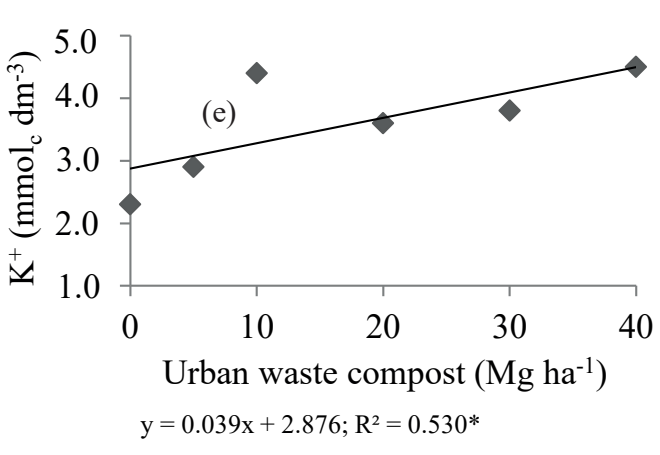

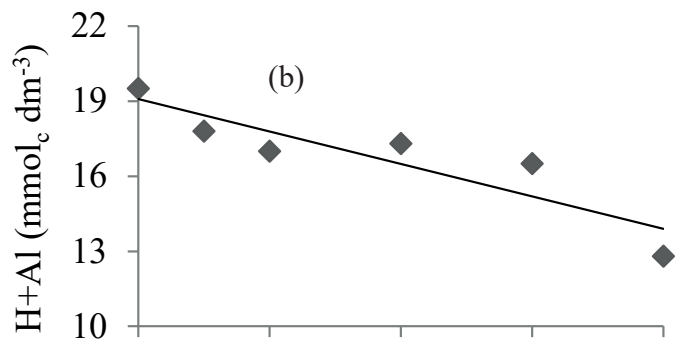

$y=-0.130 x+19.067 ; R^{2}=0.805 * *$
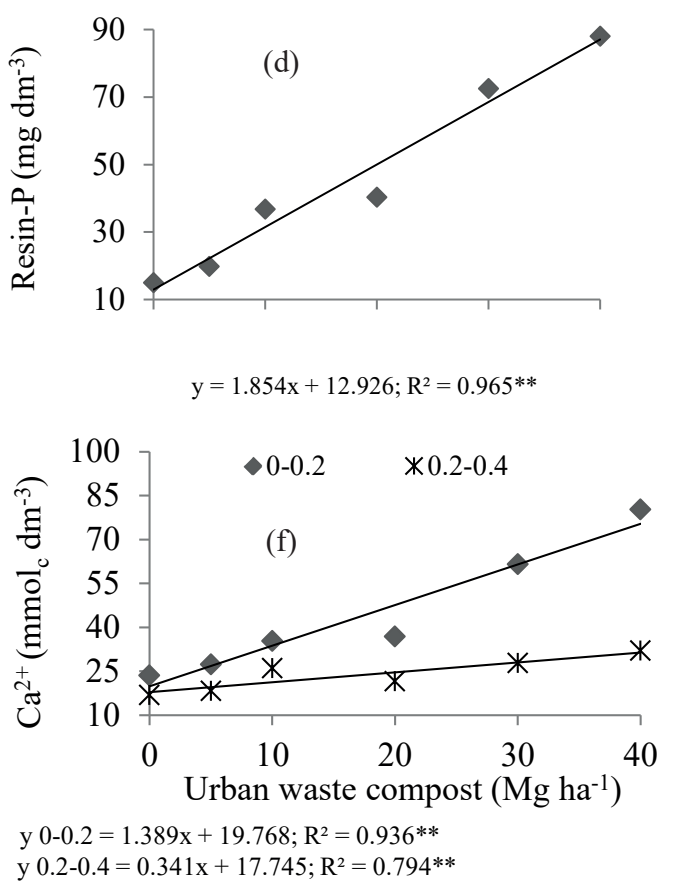

Figure 2. $\mathrm{pH}$ values (a), potential acidity (b), organic matter concentration (c), $\mathrm{P}(\mathrm{d}), \mathrm{K}^{+}$(e) and $\mathrm{Ca}^{2+}(\mathrm{f})$ of the soil, in the $0-0.2 \mathrm{~m}$ layer, and $\mathrm{pH}$ values and $\mathrm{Ca}^{2+}$ concentration in the 0.2-0.4 m layer, in response to fertilization with urban waste compost. 
$\mathrm{OH}^{-}$ions during the mineralization of the organic carbon from the urban waste compost (Hargreaves et al. 2008). Similar results were reported by Krob et al. (2011) and Strojaki et al. (2013), who confirmed the mitigating effect of urban waste compost on soil acidity under field conditions.

The organic matter concentration in the 0-0.2 $\mathrm{m}$ soil layer increased up to the estimated rate of $38 \mathrm{Mg} \mathrm{ha}^{-1}$ of urban waste compost, and, under this condition, the value would be 1.5 times greater than that of the control treatment (Figure 2c). A linear increase in the organic $\mathrm{C}$ concentration and, consequently, in the organic matter, in the $0-0.1 \mathrm{~m}$ soil layer, in a no-tillage system, after the application of up to $75 \mathrm{~m}^{3} \mathrm{ha}^{-1}$ of urban waste compost for two consecutive years, was reported by Moraes et al. (2014).

Due to the composting process, the organic carbon from the urban waste compost is in more stable forms and less susceptible to mineralization. Therefore, most of it remains in the soil as an organic matter component, rather than being released into the atmosphere in the form of $\mathrm{CO}_{2}$ (Chácon et al. 2011).

The concentrations of resin-extracted $\mathrm{P}$ and $\mathrm{K}^{+}$ and $\mathrm{Ca}^{2+}$, in the $0-0.2 \mathrm{~m}$ soil layer, increased linearly with the urban waste compost rates, with 6.7, 1.5 and 3.8-fold increases, respectively, if compared to the control with the treatment fertilized with $40 \mathrm{Mg} \mathrm{ha}^{-1}$ of urban waste compost (Figures 2d, 2e and 2f). As the increase was linear for these nutrients, the application of urban waste compost rates exceeding $40 \mathrm{Mg} \mathrm{ha}^{-1}$ would result in even greater increases.

The application of urban waste compost in the planting furrow linearly increased the $\mathrm{pH}$ in $\mathrm{CaCl}_{2}$ and the soil $\mathrm{Ca}^{2+}$ concentrations, in the $0.2-0.4 \mathrm{~m}$ soil layer (Figures $2 \mathrm{a}$ and $2 \mathrm{f}$ ). In relation to the $\mathrm{pH}$, there was a unit increase of 0.7 , and the $\mathrm{Ca}^{2+}$ concentrations increased 1.8-fold by the application of $40 \mathrm{Mg} \mathrm{ha}^{-1}$ of urban waste compost. Similar results were reported by Mantovani et al. (2005), in an experiment using lysimeters. The authors stated that the incorporation of up to $120 \mathrm{Mg} \mathrm{ha}^{-1}$ of urban waste compost in the 0-0.2 m soil layer improved soil fertility in this layer, as well as in the 0.2-0.4 m layer, where increases in $\mathrm{pH}$ and $\mathrm{Ca}^{2+}$ concentrations were also detected.

The organic matter, resin $\mathrm{P}$ and $\mathrm{K}^{+}$ concentrations, in the $0.2-0.4 \mathrm{~m}$ soil layer, were unaltered $(p>0.05)$ with the application of urban waste compost, and the average values observed were, respectively, $13 \mathrm{~g} \mathrm{dm}^{-3}, 11 \mathrm{mg} \mathrm{dm}^{-3}$ and
$2.7 \mathrm{mmol}_{\mathrm{c}} \mathrm{dm}^{-3}$. In relation to $\mathrm{Mg}^{2+}$ in the $0-0.2 \mathrm{~m}$ soil layer, the data were adjusted with a quadratic model, with increases in concentrations in response to the estimated rate of $12 \mathrm{Mg} \mathrm{ha}^{-1}$ of urban waste compost and a 1.4-fold increase in the concentrations, when comparing the treatments of the extreme compost rates of $0 \mathrm{Mg} \mathrm{ha}^{-1}$ and $40 \mathrm{Mg} \mathrm{ha}^{-1}$ (Figure 3a).

The effective and potential cation exchange capacity, as well as the base saturation (V\%) of the soil, varied in the $0-0.2 \mathrm{~m}$ layer, respectively, from $52 \mathrm{mmol}_{\mathrm{c}} \mathrm{dm}^{-3}, 77 \mathrm{mmol}_{\mathrm{c}} \mathrm{dm}^{-3}$ and $62 \%$, in the control treatment, to $75 \mathrm{mmol}_{\mathrm{c}} \mathrm{dm}^{-3}, 89 \mathrm{mmol}_{\mathrm{c}} \mathrm{dm}^{-3}$ and $84 \%$, in the treatment fertilized with the highest rate of the organic residue (Figures $3 b, 3 c$ and $3 d$ ).

The presence of these nutrients in the composition of the urban waste compost explains the results observed. Moreover, in the case of $\mathrm{P}$, increasing the $\mathrm{pH}$ and soil organic matter decrease the nutrient adsorption to the solid phase components of the soil, increasing plant availability (Mantovani et al. 2005, Souza Júnior et al. 2012, Arruda et al. 2015). Increased macronutrient concentrations in the soil surface layer (0-0.2 m), after urban waste compost application in the field, were also reported by Krob et al. (2011) and Strojaki et al. (2013).

The soil $\mathrm{B}$ and $\mathrm{Zn}$ concentrations in the 0-0.2 $\mathrm{m}$ soil layer increased linearly after the urban waste compost application (Figures $3 \mathrm{e}$ and $3 \mathrm{f}$ ). The $\mathrm{B}$ and $\mathrm{Zn}$ concentrations increased 1.5 and 2.8-fold, respectively, when comparing the control treatment and fertilization with $40 \mathrm{Mg} \mathrm{ha}^{-1}$ of urban waste compost. The B and $\mathrm{Zn}$ concentrations of the treatments were, respectively, within the medium and high concentration class presented by Raij et al. (1997). In the 0.2-0.4 $\mathrm{m}$ soil layer, the $\mathrm{Mg}^{2+}, \mathrm{B}$ and $\mathrm{Zn}$ concentrations were unaltered $(\mathrm{p}>0.05)$ with the application of urban waste compost, and the average values observed were, respectively, $6 \mathrm{mmol}_{\mathrm{c}} \mathrm{dm}^{-3}$, $0.3 \mathrm{mg} \mathrm{dm}^{-3}$ and $2.9 \mathrm{mg} \mathrm{dm}^{-3}$.

The soil concentrations of $\mathrm{SO}_{4}{ }^{2-} \mathrm{S}, \mathrm{Cu}, \mathrm{Fe}$, $\mathrm{Mn}$ and of the toxic heavy metals $\mathrm{Ni}$ and $\mathrm{Pb}$, in the $0-0.2 \mathrm{~m}$ and $0.2-0.4 \mathrm{~m}$ layers, were not altered $(\mathrm{p}>0.05)$ with the application of urban waste compost. In the $0-0.2 \mathrm{~m}$ layer, the average concentrations detected were, respectively, $4 \mathrm{mg} \mathrm{dm}^{-3}$, $1.4 \mathrm{mg} \mathrm{dm}^{-3}, 21 \mathrm{mg} \mathrm{dm}^{-3}, 4.6 \mathrm{mg} \mathrm{dm}^{-3}, 0.13 \mathrm{mg} \mathrm{dm}^{-3}$ and $1.13 \mathrm{mg} \mathrm{dm}^{-3}$, while, in the 0.2-0.4 m layer, the values were $6 \mathrm{mg} \mathrm{dm}^{-3}, 13 \mathrm{mg} \mathrm{dm}^{-3}, 16 \mathrm{mg} \mathrm{dm}^{-3}$, $3.2 \mathrm{mg} \mathrm{dm}^{-3}, 0.09 \mathrm{mg} \mathrm{dm}^{-3}$ and $1.02 \mathrm{mg} \mathrm{dm}^{-3}$. The amounts of these chemical elements supplied to the 
soil with the application of the urban waste compost rates were not high. In addition, in the soil occurred insolubilization reactions of these chemical elements and, with this, the changes in the available contents were not detected by the soil analysis. The soil $\mathrm{Cd}$ and $\mathrm{Cr}$ concentrations in the $0-0.2 \mathrm{~m}$ and $0.2-0.4 \mathrm{~m}$ soil layers were below the detection limit of the optical emission spectrometer (ICP-OES).

Linear increases in the $\mathrm{Cu}, \mathrm{Zn}, \mathrm{Ni}$ and $\mathrm{Pb}$ concentrations were reported by Sampaio et al. (2009), in an experiment using pots, and no Cd was detected in soils with different clay concentrations, in response to rates equivalent to up to $90 \mathrm{Mg} \mathrm{ha}^{-1}$ of urban waste compost. The differences between these and the results of our study can be explained by the urban waste compost rates applied, which were lower in this experiment.

Fertilization with urban waste compost had a quadratic effect on maize grain yield and, according to the regression equation, the maximum yield $\left(12,803 \mathrm{~kg} \mathrm{ha}^{-1}\right)$ would be obtained with an estimated rate of $34 \mathrm{Mg} \mathrm{ha}^{-1}$ of urban waste compost (Figure 4a). It was also found that a rate of $30 \mathrm{Mg} \mathrm{ha}^{-1}$ of urban waste compost provided $99.7 \%$ of the maximum yield, and this value was 1.3-fold that of the control treatment. Increases in crop yields in the field were also obtained by fertilization with urban waste compost by Strojaki et al. (2013) and Weber et al. (2014).

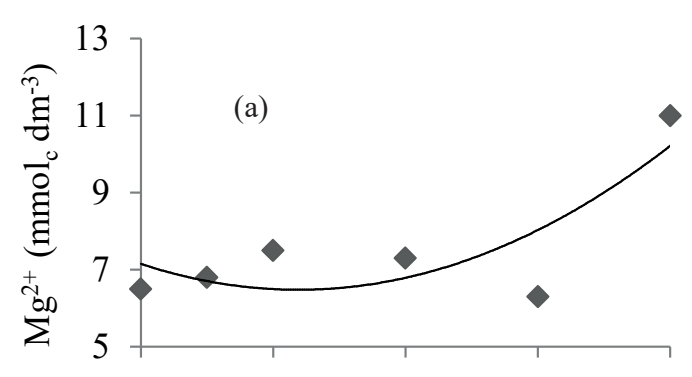

$\mathrm{y}=0.0048 \mathrm{x}^{2}-0.117 \mathrm{x}+7.149 ; \mathrm{R}^{2}=0.649 * *$

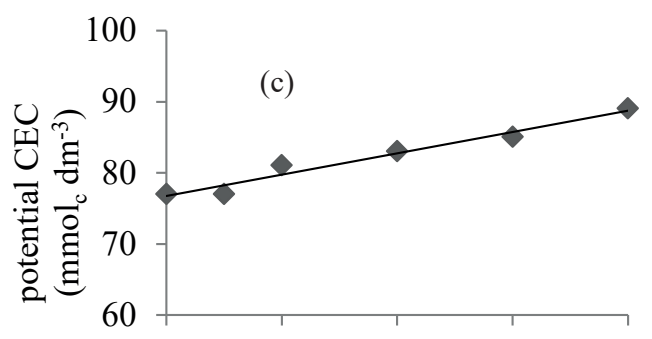

$\mathrm{y}=0.298 \mathrm{x}+76.768 ; \mathrm{R}^{2}=0.965 * *$

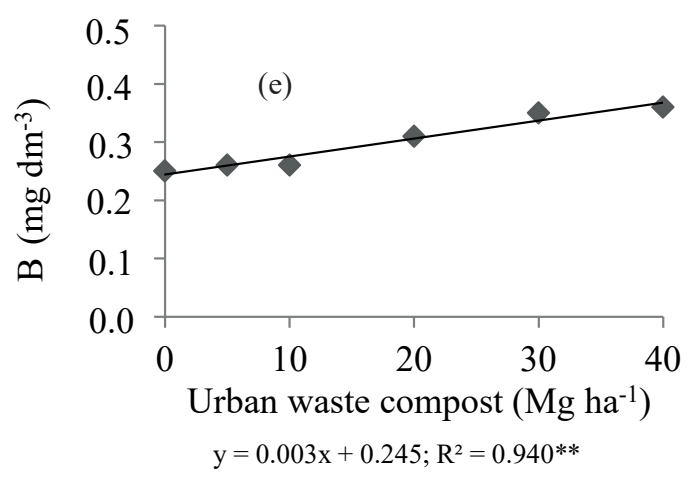

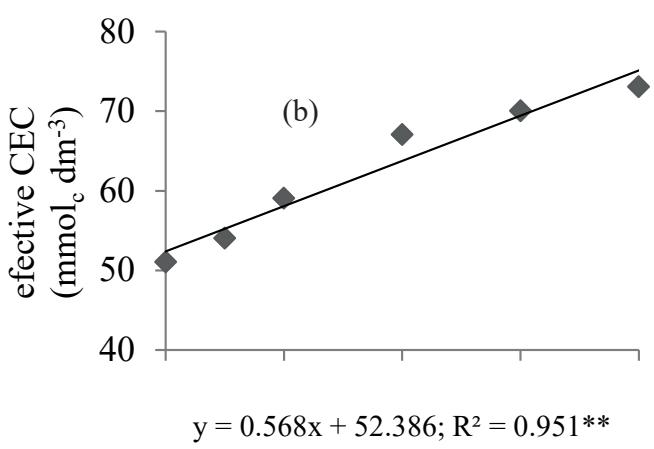

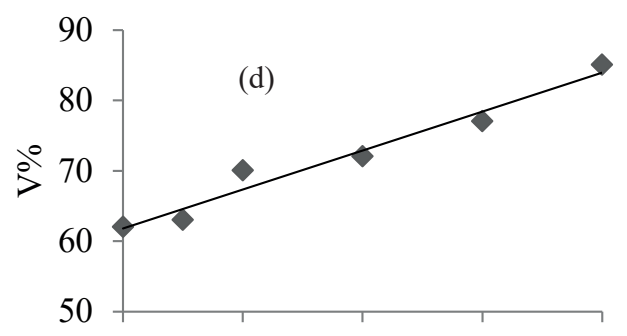

$\mathrm{y}=0.553 \mathrm{x}+61.811 ; \mathrm{R}^{2}=0.964 * *$

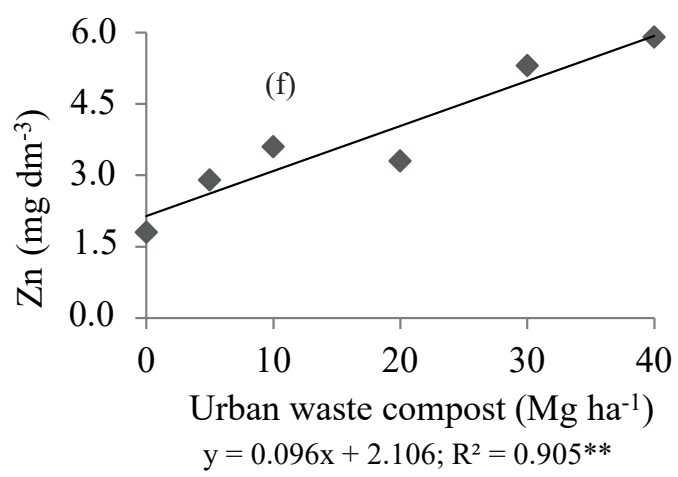

Figure 3. Mg concentration (a), effective (b) and potential (c) cation exchange capacity, base saturation values (d), B (e) and Zn (f) concentrations, in the $0-0.2 \mathrm{~m}$ soil layer, in response to fertilization with urban waste compost. 
The average maize grain yield in all treatments, including the control, clearly exceeded the average yield of the Center-South region of Brazil, which was $6,910 \mathrm{~kg} \mathrm{ha}^{-1}$ for the first-crop maize, in the 2015/2016 growing season (Conab 2016). The high grain yield in the control treatment $\left(9,775 \mathrm{~kg} \mathrm{ha}^{-1}\right)$ was due to the good initial soil fertility of the area and the appropriate climatic conditions (temperature and precipitation) during the experiment.

The yield components (ear length, number of grains per ear and 1,000-grain weight) increased linearly with urban waste compost rates (Figures $4 \mathrm{~b}$, $4 \mathrm{c}$ and $4 \mathrm{~d}$ ) and, with the application of the highest rate of this organic residue, the values were 1.16 , 1.12 and 1.06 higher than those of the control. On the other hand, ear diameter was not altered $(p>0.05)$ by urban waste compost applications, with an average value of $5.2 \mathrm{~cm}$.

Increases in grain yield and maize yield components may be explained by the raise in nutrients concentrations in the soil, with the application of urban waste compost (Figure 2).

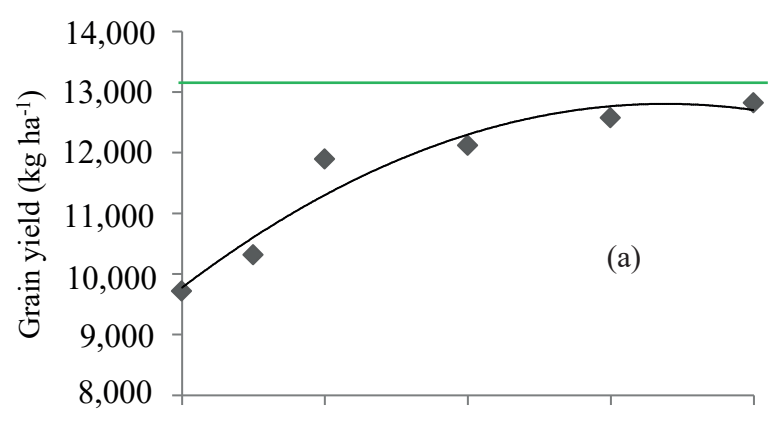

$y=-2.650 x^{2}+179.170 x+9774.55 ; R^{2}=0.935 * *$

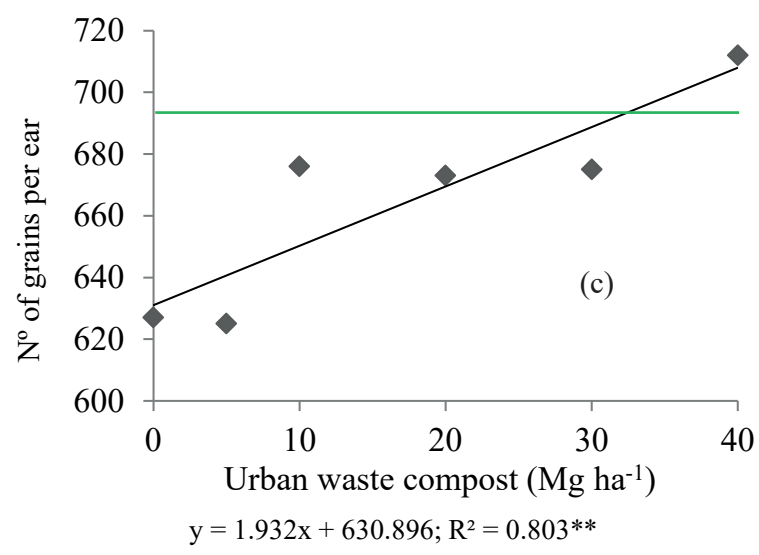

In the treatments fertilized with the two highest urban waste compost rates $\left(30 \mathrm{Mg} \mathrm{ha}^{-1}\right.$ and $40 \mathrm{Mg} \mathrm{ha}{ }^{-1}$ ), the maize grain yield, ear length, ear diameter and number of grains per ear were similar to the additional treatment with mineral fertilization, indicating that, for maize, these organic urban waste compost rates can substituted mineral fertilization. Similar results were described by Strojaki et al. (2013), under field conditions, where rates of $40 \mathrm{Mg} \mathrm{ha}^{-1}$ of urban waste compost substituted mineral fertilization in sunflower and maize, without altering crop yields.

There was a linear increase in $\mathrm{P}$ and $\mathrm{K}$ leaf concentrations with increasing urban waste compost rates, and $\mathrm{N}$ leaf concentrations augmented up to an estimated rate of $27 \mathrm{Mg} \mathrm{ha}^{-1}$ of the organic fertilizer (Table 4). In the grains, higher N, P and K concentrations were also observed after fertilization with urban waste compost.

The other nutrients evaluated in the leaf tissue and maize grains were not affected $(p>0.05)$ by the urban waste compost application. In these plant parts,

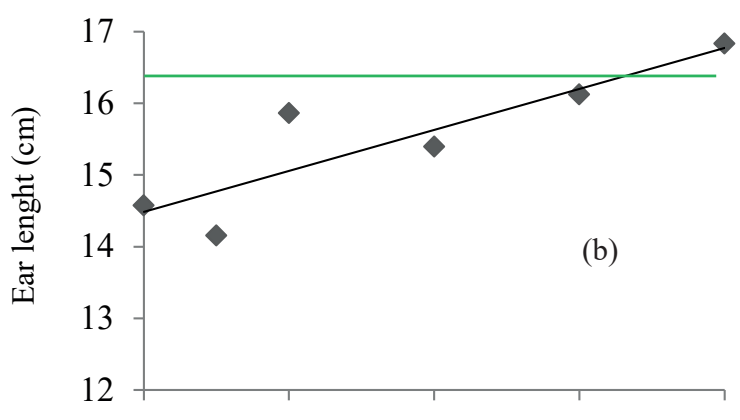

$\mathrm{y}=0.057 \mathrm{x}+14.501 ; \mathrm{R}^{2}=0.775^{* *}$

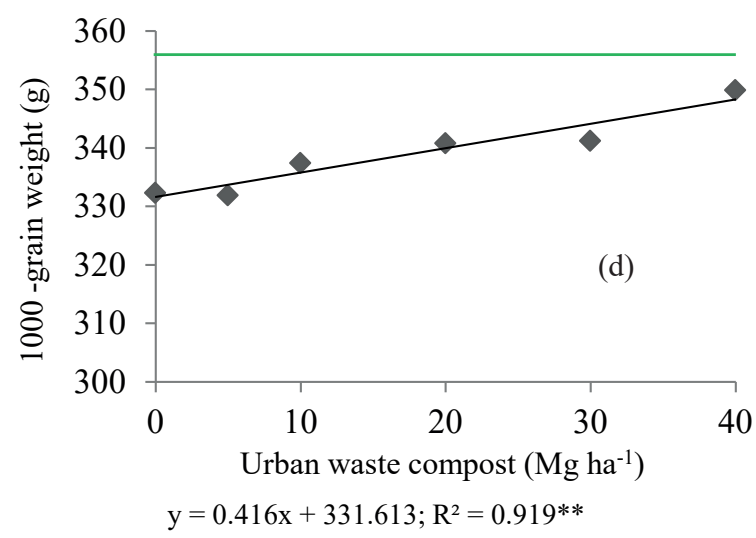

Figure 4. Grain yield (a), ear length (b), number of grains per ear (c) and 1,000-grain weight (d), as a function of organic waste compost rates or additional treatment (mineral fertilization — - ). 
Table 4. Regression equations for nutrient concentrations in leaf tissue and maize grains (y), in response to urban waste compost rates $(\mathrm{x})$.

\begin{tabular}{llll}
\hline \multicolumn{2}{c}{ Dependent variable $\left(\mathrm{g} \mathrm{kg}^{-1}\right)$} & \multicolumn{1}{c}{ Equation } & $\mathrm{R}^{2}$ \\
\hline Leaves & & & \\
& $\mathrm{N}$ & $\mathrm{Y}=30.988+0.188 \mathrm{X}-0.0035 \mathrm{X}^{2}$ & $0.805^{* *}$ \\
& $\mathrm{P}$ & $\mathrm{Y}=1.816+0.009 \mathrm{X}$ & $0.710^{* *}$ \\
& $\mathrm{~K}$ & $\mathrm{Y}=18.019+0.058 \mathrm{X}$ & $0.764^{* *}$ \\
\hline Grains & & \\
& $\mathrm{N}$ & $\mathrm{Y}=13.726+0.052 \mathrm{X}$ & $0.884^{* *}$ \\
& $\mathrm{P}$ & $\mathrm{Y}=4.062-0.029 \mathrm{X}+0.0015 \mathrm{X}^{2}$ & $0.840^{* *}$ \\
& $\mathrm{~K}$ & $\mathrm{Y}=4.295-0.057 \mathrm{X}+0.0018 \mathrm{X}^{2}$ & $0.676^{* *}$ \\
\hline
\end{tabular}

** Significant $(\mathrm{p}<0.01)$.

the concentrations of the heavy metals $\mathrm{Cd}, \mathrm{Cr}, \mathrm{Ni}$ and $\mathrm{Pb}$ were undetectable.

\section{CONCLUSIONS}

1. Fertilization with up to $40 \mathrm{Mg}^{-1}$ of urban waste compost in a single application improves soil fertility;

2. Fertilization with urban waste compost increases grain yield and $\mathrm{N}, \mathrm{P}$ and $\mathrm{K}$ concentrations in leaf tissue and maize grains, without inducing plant contamination with heavy metals;

3. The application of $30 \mathrm{Mg} \mathrm{ha}^{-1}$ of urban waste compost can replace mineral fertilization in maize cultivation.

\section{ACKNOWLEDGMENTS}

The authors are grateful to the Fundação de Amparo à Pesquisa de Minas Gerais (Fapemig), for funding this research.

\section{REFERENCES}

ARRUDA, E. M.; LANA, R. M. Q.; PEREIRA, H. S. Fósforo extraído por Mehlich e resina de troca aniônica em solos submetidos à calagem. Bioscience Journal, v. 31, n. 4, p. 1107-1117, 2015.

ASSOCIAÇÃO BRASILEIRA DE EMPRESAS DE LIMPEZA PÚBLICA E RESÍDUOS ESPECIAIS (Abrelpe). Panorama dos resíduos sólidos no Brasil. 2015. Available at: $<$ http://www.abrelpe.org.br/Panorama/ panorama2015.pdf > Access on: 17 Jun., 2017.

BRASIL. Ministério da Agricultura Pecuária e Abastecimento. Instrução Normativa SDA $n^{\circ} 27$, de 05 de junho de 2006. 2006. Available at: <http://www. agricultura.gov.br/assuntos/insumos-agropecuarios/ insumos-agricolas/fertilizantes/legislacao/in-sda-27de-05-06-2006-alterada-pela-in-sda-07-de-12-4-16republicada-em-2-5-16.pdf $>$. Access on: 17 Jun., 2017.

CAMARGO, A. O. et al. Métodos de análise química, mineralógica e fisica de solos do Instituto Agronômico de Campinas. Campinas: Instituto Agronômico, 2009. (Boletim técnico, 106).

CARNEIRO, W. J. O. et al. Mineralização de nitrogênio em Latossolos adubados com resíduos orgânicos. Revista Brasileira de Ciência do Solo, v. 37, n. 3, p. 715-725, 2013.

CHACÓN, E. A. V. et al. Decomposição de fontes orgânicas e mineralização de formas de nitrogênio e fósforo. Revista Ceres, v. 58, n. 3, p. 373-383, 2011.

COMPANHIA NACIONAL DE ABASTECIMENTO (Conab). Acompanhamento da safra brasileira: grãos, $11^{\circ}$ levantamento, safra 2015/2016. 2016. Available at: <http://www.conab.gov.br/OlalaCMS/uploads/ arquivos/16_08_09_12_08_19_boletim_graos_ agosto_2016.pdf $>$. Access on: 10 Nov., 2016.

EMPRESA BRASILEIRA DE PESQUISA AGROPECUÁRIA (Embrapa). Sistema brasileiro de classificação de solos. 3. ed. Brasília, DF: Embrapa, 2013.

FARIAS, A. P. et al. Produtividade da Heliconia psittacorum x Heliconia pathocircinada cv. Golden Torch sob diferentes fontes de adubação orgânica. Revista Brasileira de Engenharia Agrícola e Ambiental, v. 17, n. 7, p. 713-720, 2013.

HARGREAVES, J. C.; ADL, M. S.; WARMAN, P. R. A review of the use of composted municipal solid waste in agriculture. Agriculture, Ecosystems and Environment, v. 123, n. 1, p. 1-14, 2008.

KROB, A. D. et al. Propriedades químicas de um Argissolo tratado sucessivamente com composto de lixo urbano. Ciência Rural, v. 41, n. 3, p. 433-439, 2011. 
LIMA, R. L. S. et al. Atributos químicos de substrato de composto de lixo orgânico. Revista Brasileira de Engenharia Agrícola e Ambiental, v. 15, n. 2, p. 185-192, 2011.

MANTOVANI, J. R. et al. Alterações nos atributos de fertilidade em solo adubado com composto de lixo urbano. Revista Brasileira de Ciência do Solo, v. 29, n. 5, p. 817824, 2005.

MORAES, M. T. et al. Changes in a Rhodic Hapludox under no-tillage and urban waste compost in the northwest of Rio Grande do Sul, Brazil. Revista Brasileira de Ciência do Solo, v. 38, n. 4, p. 1327-1336, 2014.

NOBILE, F. O.; GAlBIATTI, J. A.; MURAISHI, R. I. Fertilizantes orgânicos e resíduos de bauxita na disponibilidade de nutrientes e nutrição da cana-de-açúcar irrigada com água potável e residuária. Comunicata Scientiae, v. 3, n. 2, p. 115-122, 2012.

PAULA, J. R. et al. Mineralização do carbono e nitrogênio de resíduos aplicados ao solo em campo. Revista Brasileira de Ciência do Solo, v. 37, n. 6, p. 1729-1741, 2013.

RAIJ, B. V. et al. Análise química para avaliação da fertilidade de solos tropicais. Campinas: Instituto Agronômico, 2001.

RAIJ, B. V. et al. Recomendações de adubação e calagem para o Estado de São Paulo. 2. ed. Campinas: Instituto Agronômico, 1997. (Boletim técnico, 100).
SAMPAIO, R. A. et al. Caracterização qualitativa e quantitativa de metais pesados em alface adubada com composto de lixo urbano. Revista Brasileira de Engenharia Agrícola e Ambiental, v. 13, suppl., p. 948-954, 2009.

SILVA, C. A. Uso de resíduos orgânicos na agricultura. In: SANTOS, G. A. et al. (Eds.). Fundamentos da matéria orgânica do solo: ecossistemas tropicais e subtropicais. 2. ed. Porto Alegre: Metrópole, 2008. p. 597-624.

SOMAVILlA, A. et al. Potencial agrícola do uso de resíduo da indústria de carnes em Latossolo Vermelho. Pesquisa Agropecuária Tropical, v. 44, n. 3, p. 311-317, 2014.

SOUZA JÚNIOR, R. F. et al. Frações de fósforo inorgânico do solo e suas correlações com fósforo quantificado por extratores e pelo milho. Revista Brasileira de Ciência do Solo, v. 36, n. 1, p. 159-169, 2012.

STROJAKI, T. V. et al. Atributos químicos do solo e produtividade de girassol e milho em função de aplicação de composto de lixo urbano. Pesquisa Agropecuária Tropical, v. 43, n. 3, p. 278-285, 2013.

TEDESCO, M. J et al. Análises de solo, plantas e outros materiais. Porto Alegre: UFRGS, 1995.

WEBER, J. et al. The effect of a sandy soil amendment with municipal solid waste compost on nitrogen uptake efficiency by plants. European Journal of Agronomy, v. 54, n. 1, p. 54-60, 2014. 